\title{
The Risk and Countermeasure Study of Chinese Enterprises Cross-Border M\&A in the New Period
}

\author{
${ }^{1}$ Aimir Sejdinaj, ${ }^{2}$ Yehou Yuan \\ ${ }^{1,2}$ School of Management, Wuhan University of Technology, Wuhan, China
}

\begin{abstract}
Pursuing Mergers and Acquisitions (M\&A) allows companies access to more markets, achieves higher revenue and influence, and generates new opportunities to exchange knowledge, thus, becoming more flexible and absorptive to new knowledge, technology and change in general. At the same time, they expose themselves to higher risks inherent in operating in the foreign country environment. This study investigates how risks affect M\&A and operations in foreign countries. Based on a critical literature review, we have conceptualized M\&A and risk relationships. In these terms, both external and internal risks were investigated. The investigation was performed on a macro and micro economic levels. The databases examined encompass Dealogic, Thomson Reuters and M\&A Reports provided by EMIS PRO. The country risks of our study model include political risks, financial risks, and economic risks. A qualitative study encompassing descriptive analysis was utilized. The theoretical findings suggest that country risks have a partial influence on M\&A deals. However, because many countries with different external obstacles still have significant acquisitions level, this implies that when making a decision of merger or acquisitions as conceptualized in our study, firms do not consider political, financial and economic country risks. Chinese M\&A was explored, and it appears that political instability during 2013 - 2015 years decreased the level of M\&A. The current finding can be explained by understanding that acquisitions' level implies the effect of the decision made to enter the market. As long as the risk does not occur in the host country, M\&A level remains unaffected. Given this, we can conclude that the state should modify the existing policy regarding M\&A. The decision of firms is rarely shaped by the risks existing in the country they plan to make the investment or purchase any company. The findings of the study are a signal for national governments to establish policies that would either ease M\&A in their countries or provide sufficient support for their firms to go abroad and perform successfully.
\end{abstract}

Keywords: Mergers and acquisitions, political risks, financial risks, economic risks, country risks, China

\section{INTRODUCTION}

In the quest for market success and sustainability, firms are often required to seek their fortune across the borders. By operating in an international market, they become less vulnerable to the volatility of their respective domestic markets. Firms that operate abroad, by having access to more markets achieve higher revenue and influence in their countries which often secures them a privileged status within their countries borders, in shape of government and policy support (Demirhan \& Masca, 2008; Anastasia, 2015; Chigbu, 2015). Such firms are also generating new opportunities to exchange knowledge and to obtain new insights thus, becoming more flexible and absorptive to new knowledge, technology and change in general. However, as a part of setting up operations, investing in a foreign market is considered to be risky. There are plenty potential barriers preventing the success of firms in foreign markets. These may include different national culture and cultural distance, new regulations and laws, lack of information access and less understanding of the overall environment, financial risks such as access to funding, inflation, and exchange rate. This type of risks can be detrimental to company existence. Financial risks, loans, banks, expenses, licenses, culture, workforce, mentality, geographical distance and less commitment, laws and regulations, bribes, bureaucracy, systems of operating, just to name a few, are potential reasons why companies may choose to stick to their 
domestic market. The general knowledge assumes that firms tend to focus on the potential risks and losses more than on rewards of entering a new market. However, this may not always be true. Given this state, we believe that it is necessary to explain how risks impact operations of foreign markets. It is especially significant as globalization trend is inevitable implying that companies will either become international or perish. For that reason, forecasting, managing, and mitigating risks is a basic requirement for firms and a topic of interest for researchers. Therefore, to contribute to the body of knowledge regarding risks, international business, we tackle the issue of risks influence on Mergers and Acquisitions. Furthermore, Chinese M\&A are described given the practical significance of the subject for the Chinese society.

\section{THE GOAL OF THE CHINESE ENTERPRISE M\&A}

\subsection{The definition of Cross-border M\&A}

FDIs have two forms, which are known as Greenfield and Brownfield. Foreign direct investments can be interpreted as financial contributions to business enterprises in another country which provide control of the enterprise or part of the business to the investor. Due to the globalization processes which erase borders between countries regarding business, the role of FDI increased dramatically during the last decades in all the industries, especially in the service sector (Kolstad, I., \& Villanger, E., 2008).

Based on the proposed theoretical findings of Dunning (2008), there are several reasons for foreign companies to start investing abroad namely:

- They are seeking for natural resources which are available or cheaper overseas. However, not only natural resources can be included in this concept, but also lower labor costs, raw materials;

- Companies are looking for the market, seeing more opportunities in the realization of the product abroad. The shift to another country helps to increase their market share and thus the revenue;

- They are seeking for efficiency by dispersing and relocating part of their activities in different countries and making benefits by increased sales.

According to the statistics provided by UNCTAD, 2014 was a year characterized by a decline in foreign direct investment, indicating $16 \%$ of the difference in comparison with previous year, which is equal to $\$ 1.23$ trillion (Fig.1). This tendency is stipulated by the instability of the global economy, a geopolitical crisis which affects the policies of the countries involved. Nonetheless, more than the half of FDI was allocated to developing countries, despite the high level of political, economic, and financial risk. Given this, it is evident that the entrepreneurs and managers are more motivated by high return on their investments than feel restricted by obstacles which can occur.

- Developed economies - Transition economies Developing economies - World total

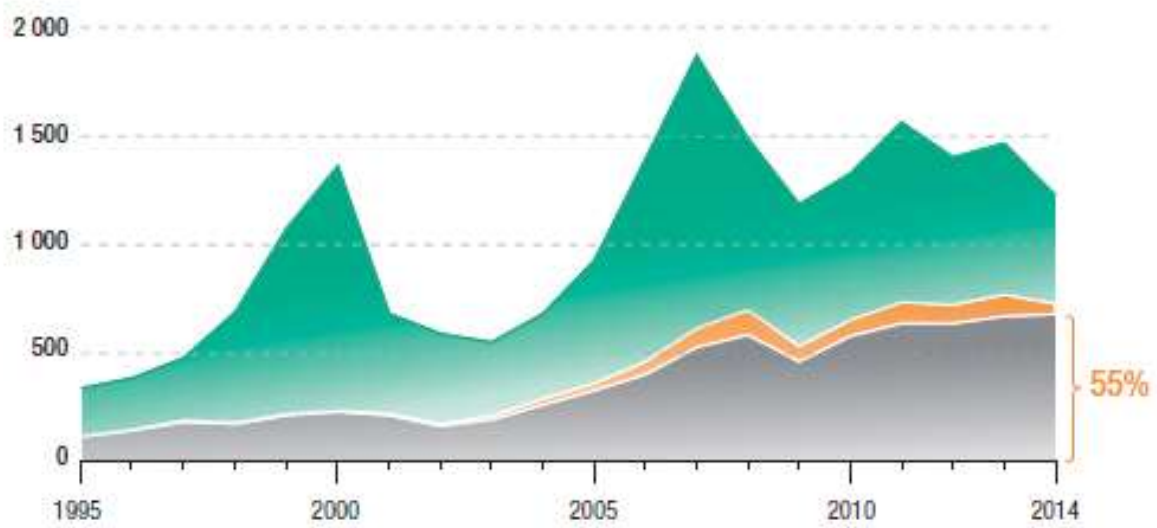

Figure 2.1: FDI, global and by group of economies, 1995-2014 (Billions of dollars) Source: UNCTAD, FDI/MNE database (www.unctad.org/fdistatistics). 
When it comes to brownfield FDI, they are synonymic to merger and acquisitions, as, in this case; the company doesn't create any other company but use the existing one. However, some authors doubt that outward foreign direct investments and M\&A are the same. Schüler-Zhou \& Schüller (2009) concluded that the growth speed of OFDI is much slower than M\&A, emphasizing that the last one is more preferable among investors. It is undoubtedly true that facing a different kind of risks; brownfield investments can have fewer obstacles in comparison to Greenfield one.

Value of cross-border M\&As and announced greenfield projects, 2003-2014 (Billions of dollars)

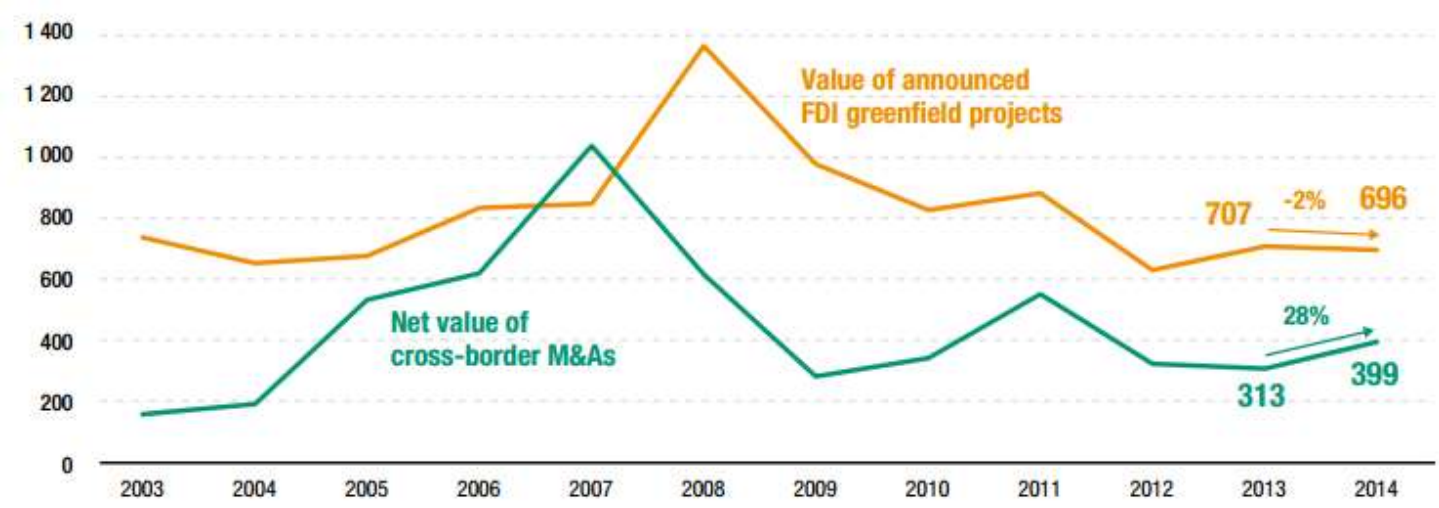

Figure 2.2: Value of cross-border M\&As during 11 years

Source: UNCTAD, cross-border M\&A database for M\&As (www.unctad.org/fdistatistics); Financial Times Ltd, fDi Markets (www.fDimarkets.com) for Greenfield projects

Companies can use the tool of M\&A to compete more effectively on the macro-level. In most cases, such merger of companies allows for both companies to increase their market, products variety, and strengths. Furthermore, companies can follow different goals by merger: starting from the wish to increase the market share within one country and ending with the expansion of the influence in the various countries and resulting in the merger of different companies. As in this process several participants are involved, in most cases, the merger happens when companies are similar. By merger, companies not only combine two markets which companies were focused on, but also start aiming the goal to seek new customers as well and try to liquidate other rivals.

When it comes to cross-border expansion, the merger can have a larger scale in different countries. Also, there is another type of merger - when a company decides to purchase another company. In this case, it is not necessarily that companies should be involved in the same business activities. Thus, $M \& A$ or in other words, merger and acquisitions mean a combination of two or more companies or purchase one by another. Analyzing the growth of global M\&A, it is evident that recently this type of FDI is receiving more attention than Greenfield one. However, there was a considerable growth in 2015 in both of them. During the first nine months, global brownfield investments accounted almost 3.5 trillion of USD.

When it comes to cross-border mergers and acquisitions, according to the statistics provided by Dialogic, last year was remarkable due to the high level of M\&A. It was mentioned that total amount of cross-border M\&A was almost 760 billion of USD during the first half year of 2015. This number indicates the highest level within the last eight years. Cross-border M\&A increased the share in total M\&A on $2 \%$ in the first half of 2015 in comparison with 2014 and by $6 \%$ compared to 2013. 


\section{Aimir Sejdinaj, Yehou Yuan}

The Risk and Countermeasure Study Of Chinese Enterprises Cross-Border M\&A In the New Period

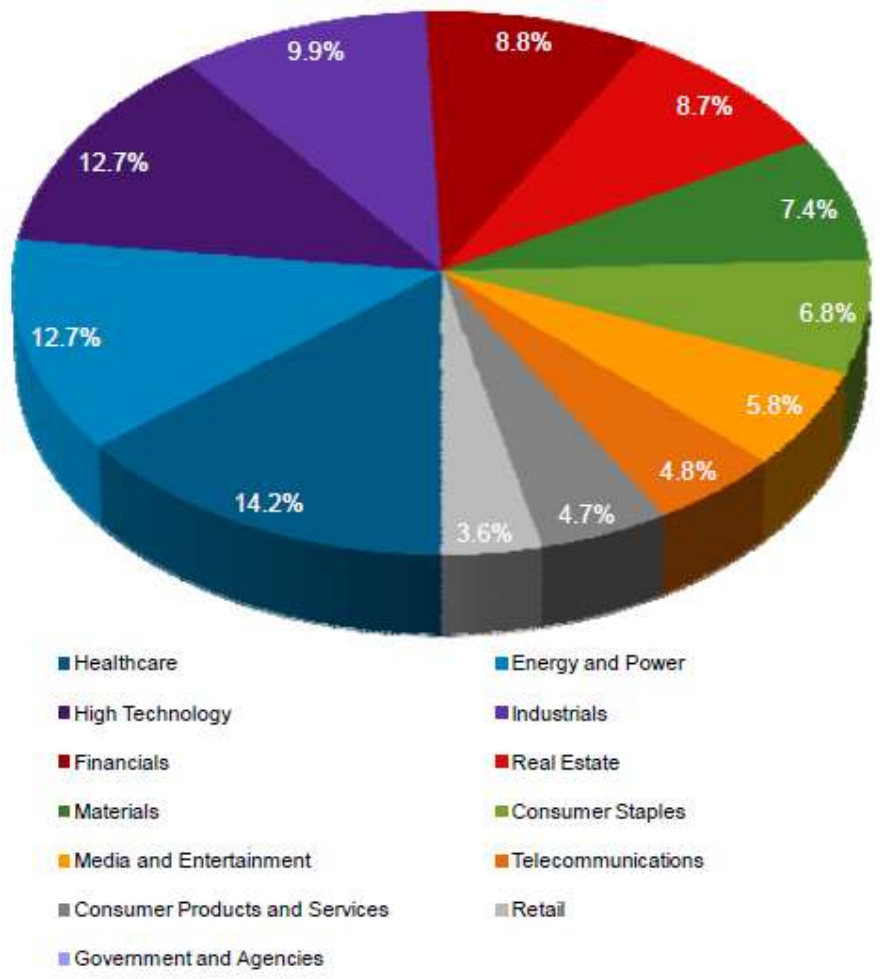

Figure 2.3: M\&A Target Industry by Value, 2015

Source: Reuters, T. (2015)

Analyzing the most attractive sectors on $M \& A$ in the first half year it is obvious that healthcare occupies almost the quarter of total M\&A receiving approximately 350 billion of USD. Meanwhile, energy, power sector, and high-tech have similar shares of $12.7 \%$. Oil and gas industry doubled its acquisition level in comparison to 2014, indicating more than 260 billion of USD, while both in healthcare and high-tech there was a significant increasing trend as well. The utility is the only sector that decreased its size, yet, only slightly. Financial and real estate together with consumer products and telecommunications can be described as pairs having similar shares in total M\&A, 8.7 \%, and 4.8 $\%$ respectively. Based on the data given, industries were estimated as the $10^{\text {th }}$ part in overall M\&A. When it comes to consumer products and services, the level of acquisitions remained almost the same as last year and hardly reached 75 billion USD, similar to the transportation sector. However, compared to the previous year, this sector nearly doubled its volume.

Table 2.1: Announced $M \& A$ by target nationality

\begin{tabular}{|c|c|c|c|c|c|}
\hline \multirow{3}{*}{ Target Notionalify } & \multicolumn{5}{|c|}{ Announced Mas by Target Rationality } \\
\hline & \multicolumn{2}{|c|}{ 1H2015 } & \multicolumn{2}{|c|}{$1 \mathrm{H} 2014$} & \multirow{2}{*}{$\begin{array}{l}\text { SrVolume } \\
\text { Change }\end{array}$} \\
\hline & Volume știn & Deals. & Volumestin & Deals & \\
\hline United States & $1,055.1$ & 5,127 & 702.2 & 5,342 & $50 \%$ \\
\hline China & 242.8 & 1,301 & 1209 & 1,789 & $101 \%$ \\
\hline United Kingdom & 206,4 & 1,229 & 85.4 & 1,165 & $142 \%$ \\
\hline Hong Kong & 104.2 & 167 & 20.3 & 220 & $413 \%$ \\
\hline France & 71.2 & 879 & 139.1 & 1,023 & -4996 \\
\hline South Korea & 65.7 & 541 & 49.2 & 456 & 345 \\
\hline Switzerland & 54.2 & 123 & 17.7 & 161 & $206 \%$ \\
\hline Australia & 46.3 & 595 & 49.5 & 660 & $-7 \%$ \\
\hline Japan & 39.8 & 1,278 & 41.0 & 1,321 & $-3 \%$ \\
\hline Canada & 39.3 & 933 & 50.6 & 889 & $-22 \%$ \\
\hline
\end{tabular}

Source: Dialogic, Global M\&A Review First Half 2015, 2015. New York 
Analysis of M\&A from target countries perspective, it is evident that the USA is occupying the leading position; its volume is almost 4.35 times more than Chinese one (242.8), which is twice more than in the first half of 2014. The UK and Hong-Kong follow China; the last had the most impressive growth in volume from 20 to 104 billion of USD, which is equal to $413 \%$ of volume change. However, the first six months of 2015 were remarkable not only for the increase of M\&A in many countries, but also there was a decrease in countries like France, Japan, Canada and Australia. Quite a considerable improvement of $206 \%$ can be seen in M\&A of Switzerland, which managed to attract acquisition for 54 billion starting from January until July.

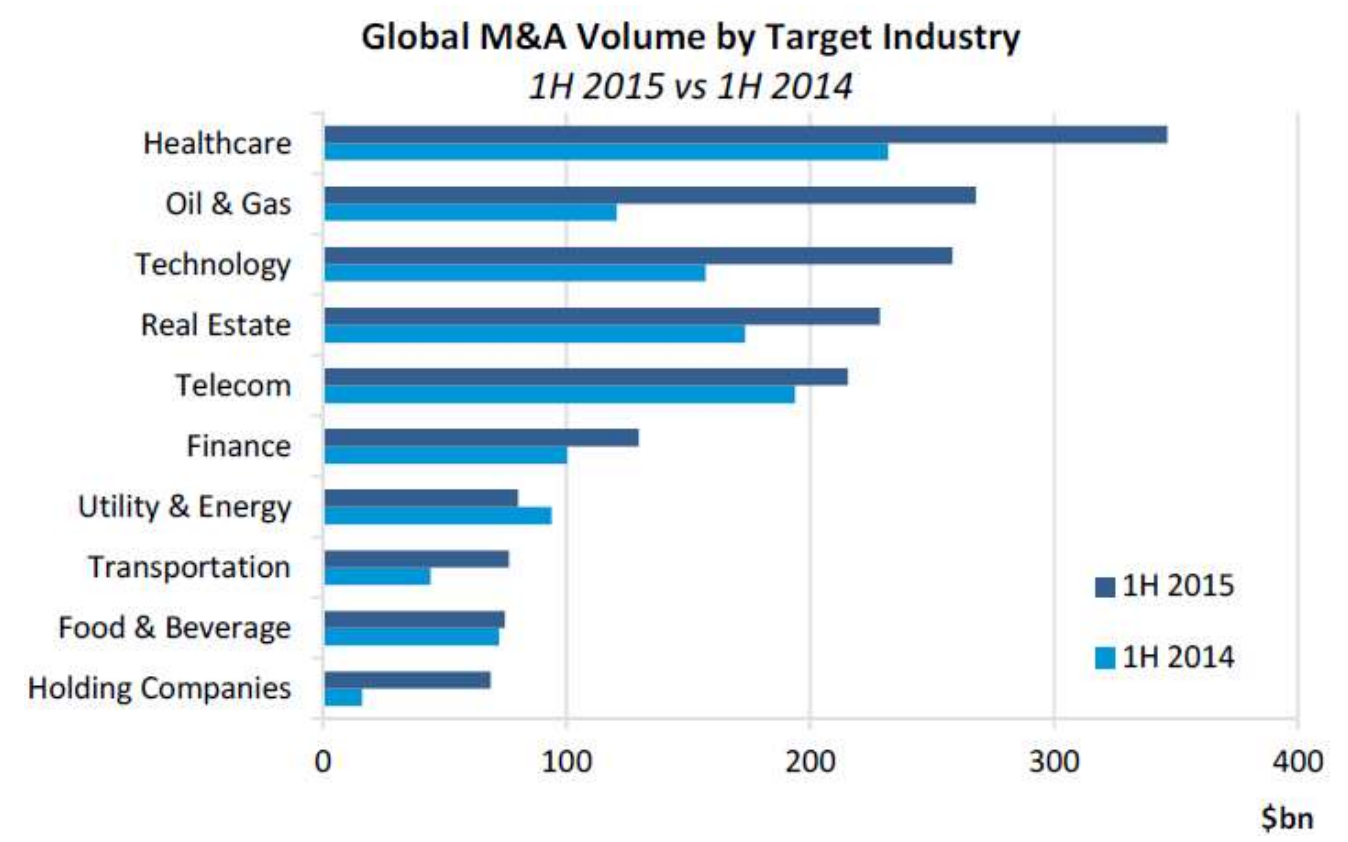

Figure 2.4: Global M\&A volume by target industry

Source: Dialogic, Global M\&A Review First Half 2015, 2015. New York

\subsection{Reasons for M\&A}

The main reason stipulating the choice of the country for the final destination of M\&A is the relatively low-interest rate. This technique provides to the USA to attract investors all over the world and accumulates the most amount of deals. Moreover, the stock market also plays a significant role in mergers and acquisitions. Volatility on the market can influence stock prices, which can serve as a tool of financing for some M\&A. The majority of companies are pursuing a constant growth that can boost their revenue. Such growth can be provided through acquisitions. In this case, M\&A is beneficial for both small and large companies. Large corporations can guarantee the growth of their business, meanwhile helping to small ones to survive or expand to global market. Nonetheless, basing on the character of M\&A, long or short-term perspective, advantages, and possible risks can be different.

Acquisition can also be considered as a mode of entry to the global market and confirmation of own position in different countries. M\&A are often used in many industries, especially in automobile one; here M\&A of Geely and Volvo can serve as a good example (Xia \& Zhang, 2011). In both cases, companies got an opportunity to strengthen their positions in both countries of their origin - China and Sweden.

\subsubsection{To obtain the technology as the guidance of M\&A}

There are several reasons, stipulating the choice of M\&A by business persons and executives of large enterprises. First of all, companies can combine their strong sides like some new trends in innovative activity, modifications, and relocation of resources or they can move part of assembly factories to the 
partner's country or company which can result in the reduction of cost expenses. The synergy between businesses allows exchanging best experience and ideas from both sides of such partnership. This process can also have a positive influence on the increasing quality of the products and services.

\subsubsection{To obtain the market as the guidance of M\&A}

By the help of M\&A, companies combine their scale of the market, which can be used as a competitive advantage. The increase of the market share can increase the benefits of the enterprise as well. Moreover, by occupying larger market share, the company can get rid of small competitors. Additionally, M\&A can be considered as a step of growth for both companies.

Here, it is necessary to mention that the process of $M \& A$ can be beneficial for the companies as the process of M\&A itself helps to promote the companies and thus their products. The news regarding $M \& A$, which involves foreign and even domestic firms, cannot be left unnoticed and thus, the companies receive additional attention, PR campaign, which usually do not require any expenses by the companies. Furthermore, in case if the acquiring and the target firms were involved in a similar sphere, they can reduce costs by optimizing their resources. It is similar to Porter's generic strategy theory, cost leadership strategy includes two main points - the growth of market share and reducing the costs.

\subsubsection{To obtain the talents as the guidance of M\&A}

Companies seeking for innovations, new technology as well as new creative human resources can pursue the goal of M\&A. Nowadays companies compete not only regarding technology, revenue or the amount of market share but also how talented their staff is. The case of the Black Cube and Apple can serve as a good example. Apple acquired "Next" not only because of the provided software but mostly because they wanted to get back the most talented leader, researcher and founder - Steve Jobs.

As a part of brownfield FDI, M\&A means the utilization of already existing buildings, as well as stuff, factors, resources. In this case, the reduplication of some departments between companies can also involve some risks like re-education of staff, elimination of some departments. All these can result in dissatisfaction among the employees and increase of the competition between them.

\section{MACRO-ENVIRONMENT ANALYSIS OF M\&A (EXTERNAL RISKS)}

\subsection{The concept of risk}

All the individuals are involved in various activities, starting from the simplest one, and there is always the possibility of force-major situations or unpredictable cases. Basing on the literature regarding the description of the risk concept, the risk is a potential threat, which can either occur or not. According to Kungwani (2014), risk can be defined as "the chance of losing something of value, weighed against the potential to gain something of value". From another hand, risks can be described as upcoming uncertain events as well.

The concept of risks cannot be judged as a negative or positive effect only. However, there are many proponents and opponents from both sides. By some authors, risks are considered as the root of some problems or additional "wave" leading to "disaster" (Simon, 1982). Furthermore, there are many opponents of the risk's concept, stating that the prediction of any threat which can theoretically occur requires much financial support. In addition to this, companies need to be flexible enough to react to any threat which can occur. Differences of preferences in goods and service due to cultural and geographical diversity make companies reorganize the whole production to satisfy the needs of the customers. 
Brand risk evaluation is an essential issue for managers of the companies seeking for acquisitions abroad. Because the company has to undertake several changes, it can effect on the whole production and reputation of the enterprise. It is essential to maintain the same level or even improve it for better. On many cases, M\&A for companies is one of the ways to escape the bankruptcy or the tool to push up the productivity of the company. Therefore, in risk management, it is essential to evaluate all the possible risks that can negatively affect acquisitions of the company as well as correctly evaluate all the features of partners' business.

However, the fear of potential threat can make firms act beforehand: calculating the possibility of the risks, potential expenses and finding any possible way to avoid or decrease the risks. From this prospect, the nature of risks contributes to the firm performance by making firms more prepared for any uncertain situations (Rasmussen, 1997). Furthermore, some cultural risks, which effect the reorganization of the company can be considered from positive perspective.Lack of knowledge of risks' consequences together with the desire of enrichment despite the high level of risks can be a reason of neglecting of the obstacles to entering the foreign market (Quer at al., 2012). Moreover, when it comes to foreign investors, they are paying more attention to the changes and instabilities in a business environment than to the country specific risks (Bevan \& Estrin, 2004).

Dealing with risks, managers of the firms are evaluating some obstacles which can appear or even not, depending on the conditions, which are not under the control of the company. As the current study is focusing on the risks on macro-level, and namely political, economic and financial risks, the reasons for their occurrence are almost unpredictable, due to the high volatility of world events.

As M\&A involves synergy between several companies, the changes in organizational structures can lead to a reorientation of the whole strategy of a new organization. According to Chen \& Wang (2014), M\&A can have two forms: 1) when both companies are fully integrated into each other and 2) when companies try to keep their independence. In the first case, companies should decide the character of their interaction - supreme and subordinate. There is a risk that subordinate firm by following the orders of the main company can lose its uniqueness, innovativeness, which attracted the supreme at initial step and was one of the main reason of M\&A. Acquisition of a small company by a larger one can result in the suppress on the former by the last one (Puranam et al., 2009). Meanwhile, the second type of M\&A can lead to misunderstanding between participants of M\&A.

\subsection{Political risks}

According to ICRG, there are several types of risks on macro-level; however, the organization is mainly focusing its attention on essentially three; financial, economic and political risks. There are several stages of the internalization of firms planning to occupy the place in the global market and it is of high importance to choose whether the company wants to deal with brownfield FDI - merger or acquisition of other companies in the host country. Based on this decision, the company can face different obstacles, which are elements of political risks. However, companies planning to invest abroad are more sensitive to political instability in the country where they are planning to invest money (Agarwal, J., \& Feils, D., 2007). Moreover, political risks are considered as one of the greatest obstacle, presented by the government, policies or institutions, for foreign companies to operate abroad (Simon, 1982; Umidjon et.al., 2014).

Political stability, considered as an opposite side of political risk, can attract the attention of foreign investors given its high level. Notwithstanding, there are some authors who doubt that a positive association between political stability and investments takes place (Blomberg et al., 2004). It can be explained that there are more random incidents, like terrorism in politically stable countries, which have opposite effect on attracting foreign investments.

Furthermore, the company can face some problems starting with the registration procedure, obtaining license and permits, and ending with the high corruption indicator, bureaucracy obstacles and lack of knowledge of certain laws in a host country. These constraints can be included in political risks. Kobrin (1979) considered political risks from two sides: as obstacles between regulatory implications and 
business operations and as events happening inside the country like devaluation and unfair taxation. In addition to this, the process of internalization needs the assurance of legacy. Therefore, the knowledge of laws and tax rate obstacles is a high priority as well.

\subsection{Economic risks}

Economic risks can be mainly presented by the indicator of GDP and economic growth. There are several studies focused on revealing the association between economic growth and cross-border foreign investments (Borensztein et al., 1998, Kholdy \& Sohrabian, 2005). Moreover, some authors doubt which of these factors influence or lead to another (Chowdhury, A., \& Mavrotas, G., 2006). Judging from the research done by Bhagwati (1978), by creating certain economic conditions and pursuing particular economic growth every year, the government makes the country more attractive for M\&A. Because economic growth is the criteria to evaluate the development of the country, foreign investors can make their decisions for countries, with increasing GDP level. However, from another side, as M\&A bring new investments to the country, it can also be considered as a push-forward element for the economic growth of the country (Alfaro et al., 2004, Busse, M., \& Hefeker, C., 2007). Furthermore, when the company acquires another and decides to set up its subsidiaries through M\&A, it brings new technology as well as innovations and new "minds" to the country. In addition to this, the process of M\&A requires additional training for the employees of the host country. Moreover, by having operations abroad, the company pays taxes to the host country, which positively affects to the enrichment of the country.

However, according to Blomberg et al. (2002), the more economic successful the country is, the higher probability that it can experience some terrorist attacks. From this, it is possible to conclude that the absence of any economic risks is not always the symbol of good investments ground. When it comes to economic risks, they have a crucial influence on the attracting foreign companies to allocate their branches or subsidiary in the countries where those risks take place. Due to the globalization that ties all countries together, there is a melt of borders between countries and especially in economic processes. These processes of each country can be characterized mostly by GDP, and economic risks are not an exemption. Basing on this indicator, the influence on the internalization of firms can be predicted. Moreover, inflation can affect the business performance of the companies as well. As the firm operating abroad has to use at least one of the factors of production (Smith, 1776), either labor, land or even capital, the prices of which can be affected by the economic situation in the host country.

\subsection{Financial risks}

After reviewing previous literature in the field of $M \& A$, internalization of firms and investments tendencies, it was found that legal, political, economic and financial risks are connected with each other. Furthermore, consideration of one cannot exclude another risk (Hermes \& Lensink, 2003). Therefore, financial risks are essential for companies as a part of the evaluation of the future market. Financial risks can be characterized as a potential factor to return the invested money or to lose it. Moreover, dealing with this uncertainty regarding brownfield FDI, the expected return of investments can be even higher, depending on the purpose of the investments.

However, according to ICRG, financial obstacles can be judged by the size of the country's debt compared to GDP on macro-level. This indicator shows the stability of the economy of the country, the measure that demonstrates the lack of production of goods and service in the country to cover its debt. Despite the fact that most countries are pursuing external debt sustainability, however, a high indicator of Total Foreign Debt as a percentage of GDP doesn't exclude the existence of economic growth in the host country (Herndon et al., 2014). Given that, there can be economic growth in the country despite total financial instability in the country.

Financial risks are tightly connected with all the financial activities of the country. Leaders and managers should always consider the possibility of occurrence of financial difficulties, especially within the entrepreneurial activity. Usually, as the companies have to deal with the currency of the country where they are operating or some international currency, they can face financial obstacles or even 
some barriers for their business activities. Therefore, high volatility of exchange rate is strongly related to financial part of foreign companies.

\subsection{Cultural risks}

Another type of risks, which had much influence on the business performance of firms, intending to operate on the global level, is cultural risks. This type of risks is out of consideration of ICRG, however, still the influence was approved by many authors, like Nordal (2001), Dutta, N., \& Roy, S. (2011), Hayakawa et al., (2013) and Erb et al. (1996).

Owing to the differences in organizational and management structures, cultural risks can be an obstacle in M\&A. Failure of Daimler-Chrysler' cooperation is an appropriate example of cultural restraints in M\&A. American and German managers of companies had their own vision of achievement, the success and different approaches in management. If both companies are equal, they "pull the blanket" in opposite directions of each other without any compromise. Adjustment and modification of management structure can be time-consuming and require additional costs.

Cultural risks include differences in preferences of the products, as there is no guarantee that the products, which are popular in one country, will have the same success in another. Furthermore, the influence of religion, traditions and customs in cultural aspect is also of great importance (Tihanyi et al., 2005). Therefore, the company should take into consideration all the aspects regarding this type of risks by showing respect to the culture of the countries, which all the marketing efforts are directed.

\begin{tabular}{|l|}
\hline OBSTACLES \\
\hline 1-Access to finance (availability and cost) \\
\hline 2-Access to land \\
\hline 3-Business licensing and permits \\
\hline 4-Corruption \\
\hline 5-Courts \\
\hline 6-Crime, theft and disorder \\
\hline 7-Customs and trade regulations \\
\hline 8-Electricity \\
\hline 9-Inadequately educated workforce \\
\hline 10-Labor regulations \\
\hline 11-Political instability \\
\hline 12-Practices of competitors in the informal sector \\
\hline 13-Tax administration \\
\hline 14-Tax rates \\
\hline 15-Transportation of goods, supplies, and inputs \\
\hline
\end{tabular}

Figure 3.1: Investment climate constraints to the establishment

Source: BEEPS (http://ebrd-beeps.com/)

\section{THE COUNTERMEASURES OF CHINESE ENTERPRISES M\&A}

\subsection{Strengthen international cooperation through mutually beneficial and win-win models of enterprise M\&A}

There are a plethora of modes of international market entry. These are manufacturing subsidiaries, strategic alliances, licensing, franchising, contracting, sales subsidiaries, direct export, indirect export, joint ventures (Brassington \& Pettitt, 2000, Armstrong \& Kotler, 2005). Therefore, considering M\&A as one of the means for entering the global market, Chinese companies should pay particular attention to the potential of mergers and acquisitions in Europe and Asia under "One Belt One Road" initiative.

China is included in Asia Pacific region. Analyzing the whole Asia-Pacific region excluding Japan, China together with Hong Kong are the leading figures. Judging from the data given by Dialogic, despite to 


\section{Aimir Sejdinaj, Yehou Yuan}

The Risk and Countermeasure Study Of Chinese Enterprises Cross-Border M\&A In the New Period

negative economic prognoses, this region has managed to accumulate more than 520 billion USD before July 2015, which is the highest growth in volume during the whole period. In comparison to 2014, 2015 was more successful by an increase of 122 billion USD, which is equal to $30 \%$ of the increase. Moreover, Asia Pacific added to the total amount of M\&A deals more than 250 billion USD between June and September. Thus, this amount of M\&A deals provided to the region makes the region occupy the top second position in the ranking after the USA and followed by Europe.

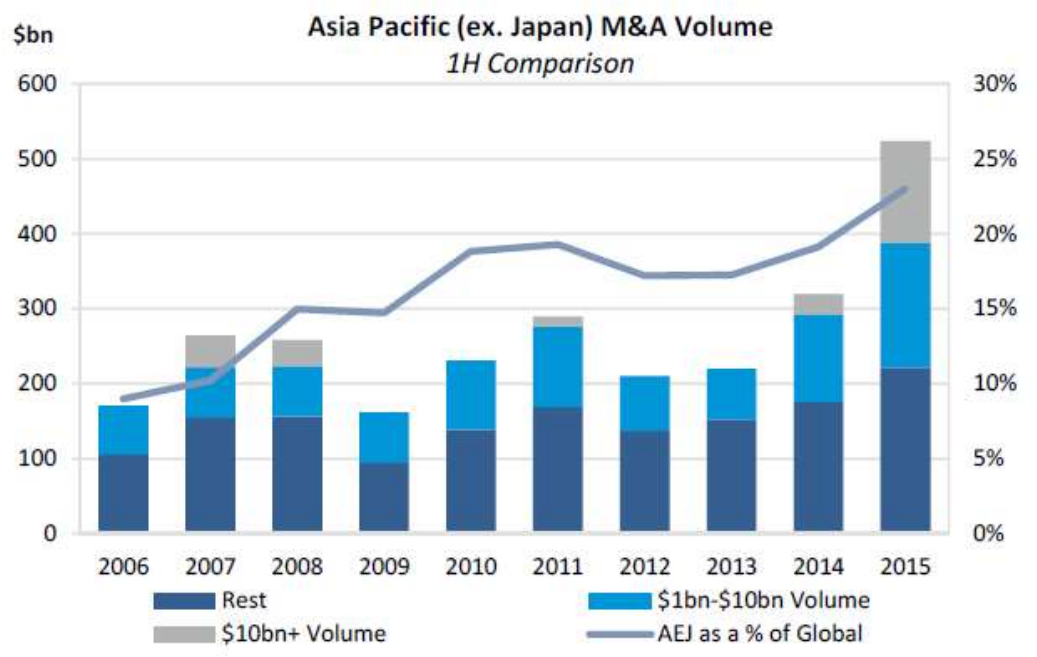

Figure 5.2: The volume of $M \& A$, Asia-Pacific

Source: Dialogic, Global M\&A Review First Half 2015, 2015. New York

Observing the countries, which contributed to such a growth of M\&A in above mentioned region, it is necessary to indicate that almost half of the total amount of M\&A were provided by the second world economy country. China accumulated deals for nearly 384 billion of USD during a nine-month period, which is almost 4.5 times more than Australia.

China was both the most investing country and the most attractive country for foreign acquisitions in Asia Pacific region which made records both in the first and the second period of 2015. Citic Group in China managed to receive investments from Japan and Thailand; three companies made a deal costing more than 10 billion USD.

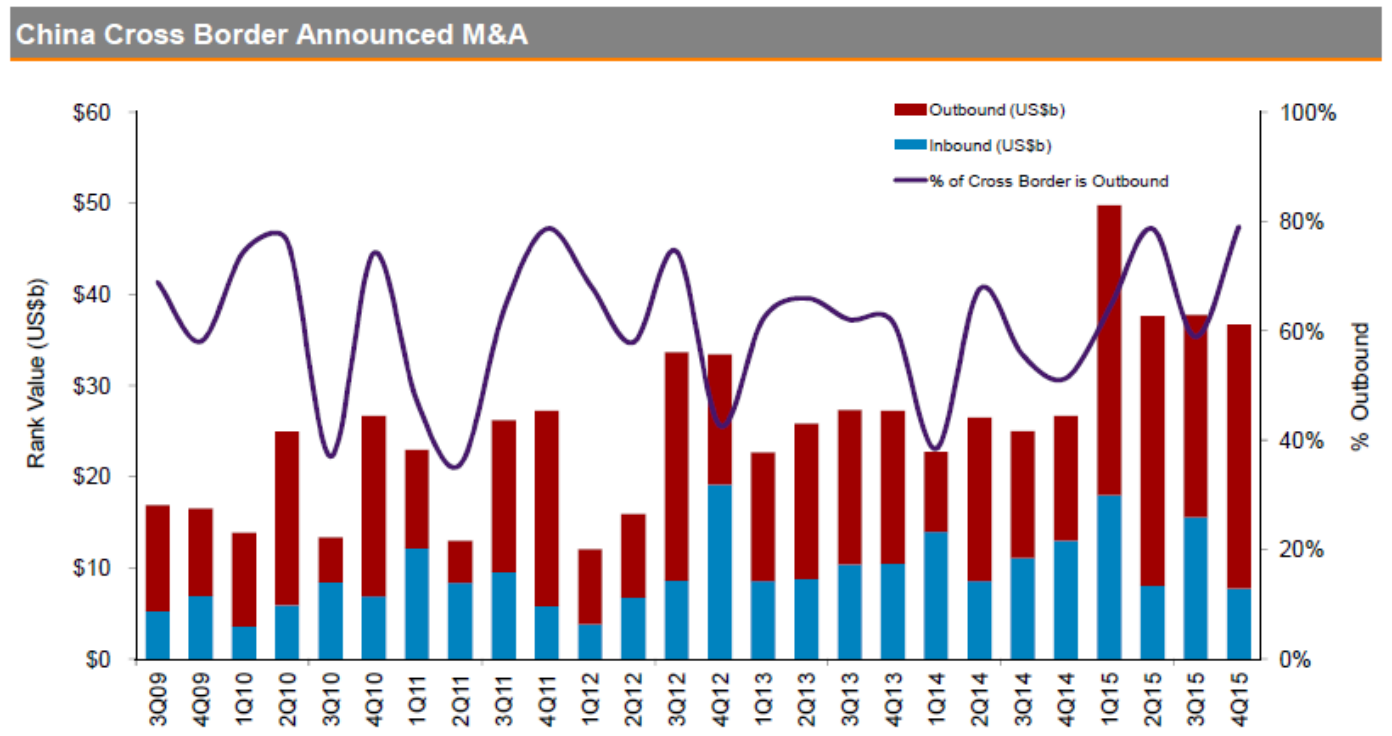

Figure 5.2: China cross-border $M \& A$

Source: Reuters, T. (2015) 
Referring to Thomson Reuters, Chinese cross-border M\&A showed a considerable growth; an increase of $61 \%$ in 2015 comparing to the previous year. OFDI accrued more than 110 billion of USD. The most attractive sector for Chinese cross-border M\&A was financial sector. According to the data, it is evident that 2015 was the most successful for China regarding outbound acquisitions.

Observing the industries, which were remarkable with highest $M \& A$, provided by Asia Pacific region, technology can be placed in the first position. According to Dialogic, this industry received nearly 79 billion of USD, which is $15 \%$ of total half year M\&A in 2015. Chinese companies (85\%) mainly provided this proportion.

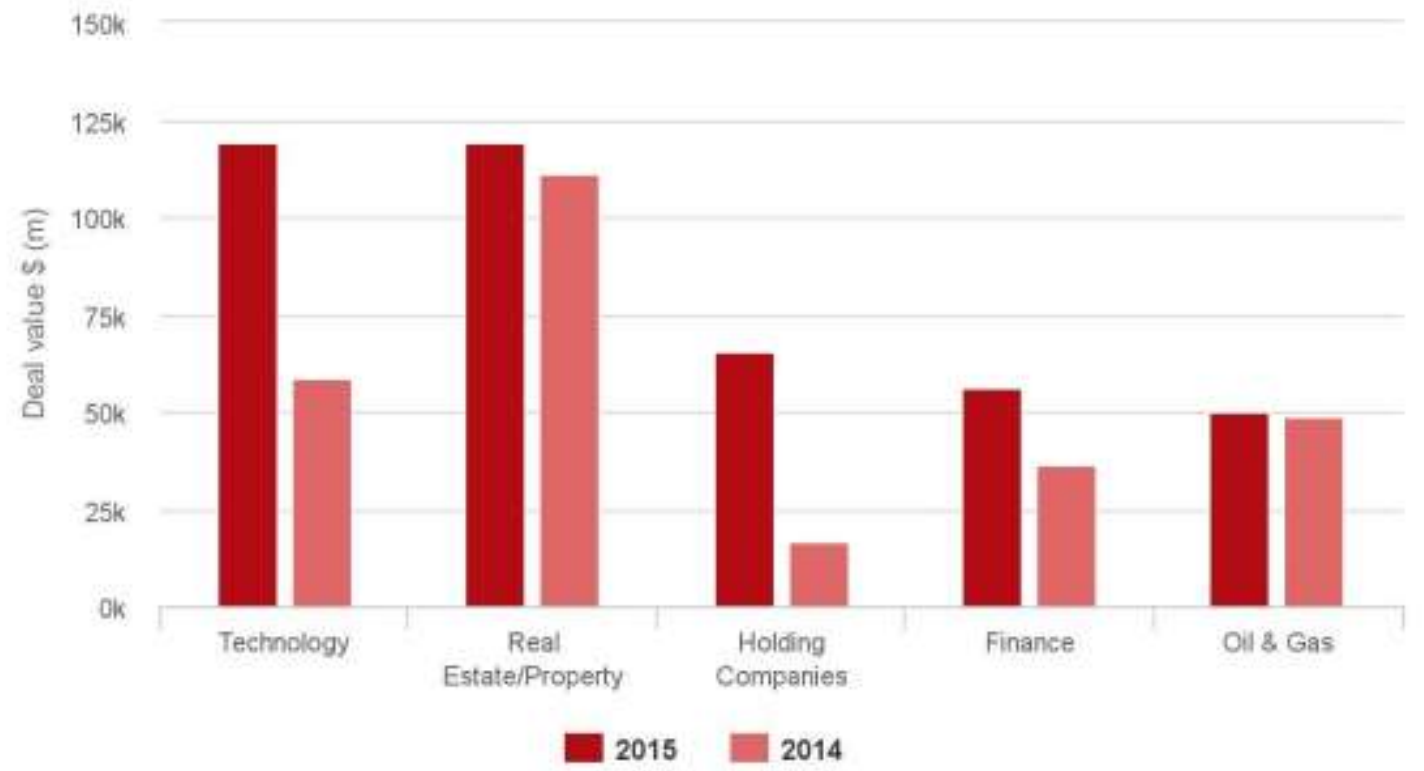

Figure 5.3: M\&A Volume by top 5 target sectors Asia Pacific Source: CNBC, 2015 (http://www.cnbc.com)

The biggest deal also belongs to Chinese company Qihoo Technology that made a deal on 9 billion of USD in that sphere. Real estate, as well as oil and gas industries, remained almost the same in comparison to 2014 (CNBC, 2015). These sectors can serve as a good example of impact or economic, financial and politic risks on the development of acquisitions. Low oil prices can also stipulate weak growth in oil and gas sector. Chinese mergers are acting carefully due to politic uncertainty and financial instability. However, the situation is improving, and Chinese investors are acquiring oil fields, mining shares in Europe. There is also a considerable improvement in the sector of holding companies, which is three times higher than in 2014.

Analysing Chinese M\&A in 2015, we can see that 33\% of deals were managed to reach the final stage, while the rest was postponed or just canceled. Nevertheless, it was enough to provide the half of announced amount of acquisitions equaled to 684 billion USD, which was twice more than in 2014. Although two years ago a number of Chinese deals was higher (1816), total value was equal only to 185 billion, which is two times less than in 2015. 


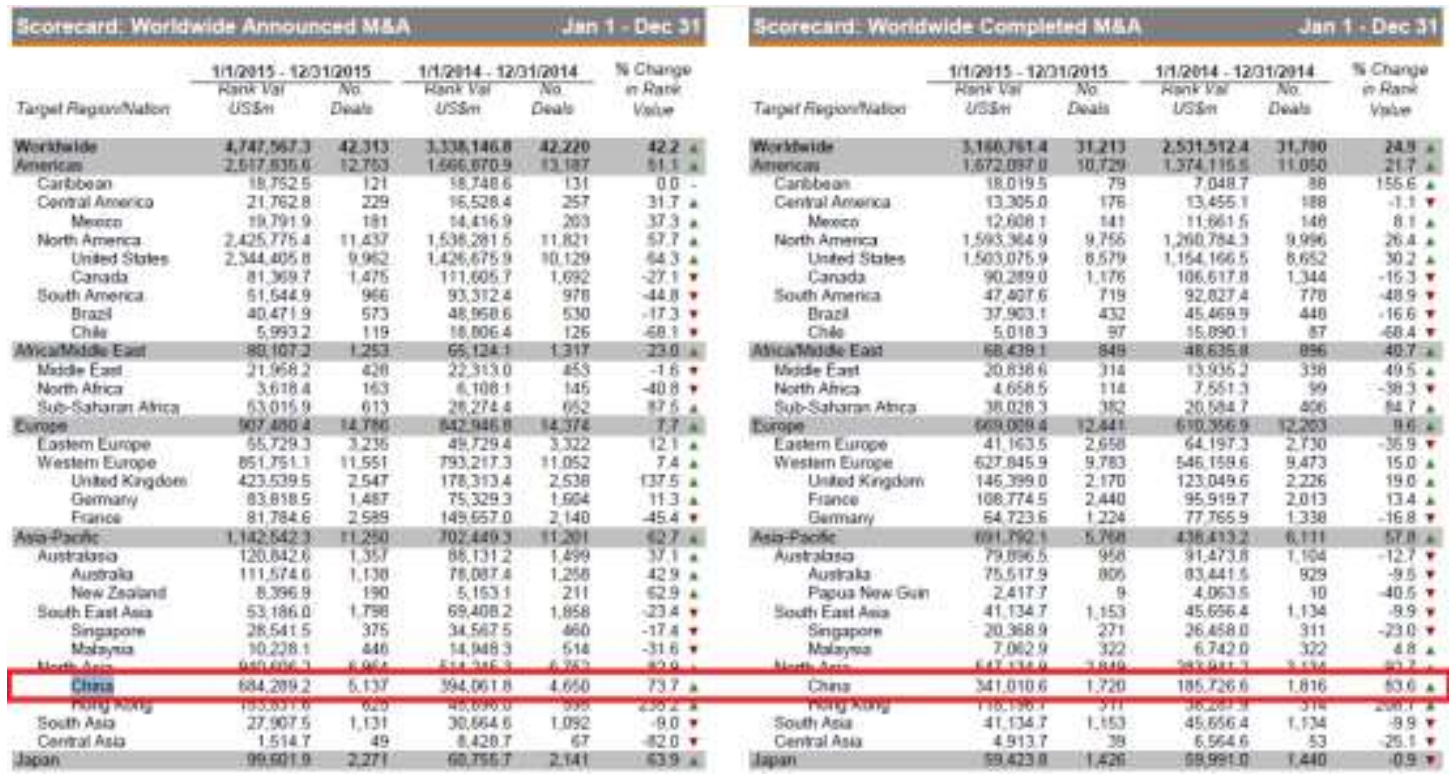

Table 5.1: Comparison between worldwide announced and completed M\&A

Source: Reuters, T. (2015)

Despite the general slowdown in the economy of China, it did not have any negative impact on investing tendency. This paradox only supports our assumption that economic, financial and politic risks have only partial influence on M\&A. China accompanied with Hong Kong are the main players on M\&A market, which are pulling up the whole Asia Pacific region. Both of them were demonstrating a remarkable increase in acquisitions in 2015.

\subsection{Policies to protect and support Chinese enterprises M\&A}

The development of an enterprise is based on the friendly relationship between countries. As a developing country, the Chinese government dedicates itself to establishing a good political and economic relationship for many years and helping China solidify its position in the world through building cooperation with other countries. As a carrier of the country's economy, enterprises can achieve the goal of mutual benefit and win-win result through merging and acquire overseas enterprises.

In recent years, the Chinese government introduced more relevant legal policies to support and guarantee the Chinese enterprises M\&A, for example, foreign exchange management policy, financial policy, national security policy and information services, etc. The government should give more support and encouragement to enterprises to develop their own transnational business overseas and utilize the markets and resources effectively between countries. Furthermore, the government should introduce relevant laws and policies to encourage enterprises to use the comparative advantages of China foreign investment and expand the economic and technologic cooperation into more areas. Also, the government should support these companies more competitively to enlarge their business by providing more funds.

China has established its dominance as a 2nd leading world economy through manufacturing and exports. Its open door policy not only led to its attraction of foreign capital but started a worldwide trend of acquisitions in developing countries, speeding up the process which has with the new globalization trends leading to numerous changes. However, in recent years, Chinese companies have also invested much of their capital into foreign countries, with companies establishing manufacturing facilities, research facilities, and other operations on foreign ground (Kolstad \& Wiig, 2012).

Investigation of external risks, which can influence of different risks acquisitions of China, we conclude that much of this initiative has been a result of Chinese government policies, which push state-owned 
enterprises and privately-owned enterprises to get involved in international operations more extensively. One of the latest initiatives came in 2013 aimed at establishing influence in the Eurasian region, through building a corridor from China to Europe through countries of Middle Asia, and the Middle East.

The "One Belt One Road" policy represents a comprehensive strategic plan for Chinese economic advancement engaging all actors of the economy system, such as financial institutions offering credits, to support systems of policy makers. As both of countries are participants and partners through this initiative, companies from these countries can be preferable and favourable in case of open tenders to make M\&A deal.

Despite governmental support, Chinese companies should take into consideration all the possible risks if they acquire any business in global terms. Although the general environment is favorable and attractive, nonetheless there are some difficulties, which Chinese companies can face, for instance, political instability, slow GDP growth and moderate domestic demand. Chinese capital, in form of M\&A, is invested in various countries, and the investment is quite diversified more exposure to current risks is present. The Chinese companies are not immune to the country risks such as political instability in other countries, economic obstacles, financial restraints and cultural differences.

\section{CONCLUSIONS AND RESEARCH PROSPECTS}

The present examination was directed on the subject of risks, M\&A, in particular Chinese. Throughout this concept, we wanted to determine whether country risks determine firm decisions of market entry and operations. More particularly, we examined political, financial and economic risks within the hot country and their relationship with FDI inflows. The complete conclusion to the study was that the variables of the research do not impact FDI inflows significantly. Our examination was critical because we have broken down and examined on how the economies may promote FDI by minimizing the risks.

The exploration was directed on both macro and micro-level analysis. The discoveries of the theorized connections of our hypothetical model recommended that there are a few procedures of the showcasing data frameworks which contribute progressively furthermore those which contribute less to a productive and fruitful choice making a result. The study resulted in valuable implications and recommendations for governments of M\&A host countries and M\&A recipient countries, firms, and businesses' leaders. The study has several important implications. Firstly, it shows that country risks are a factor to consider when companies enter the foreign market, via M\&A.

Firms are sometimes poorly informed about the risks of the host country, or find them irrelevant. Both perspectives may diminish the potential losses in the mind of the CEO when hazards occur. Given that risks do occur, and sticking with an idea that M\&A is a positive phenomenon, country should build awareness regarding risk, and create their contingency plans and risk mitigating strategies. These results represent an indicator on which particular risk firms should focus on to minimize the risk and negative impact on the performance. Furthermore, suggestions for CEOs of companies regarding risk management strategies and tools are covered in the discussion chapter of the thesis.

The significance also exists for the government, given that certain factors which are a direct result of government policy are the ones who hinder the general performance. In other words, the findings of the study are a signal for national governments to establish policies that would either ease M\&A in their countries or provide sufficient support for their firms to go abroad and perform successfully. This type of assistance can come in different shapes, such as collaboration with banks to ease the access to funding or diplomatic relations with a particular country to ease the restrictions and regulations imposed on certain industries. 
The study suffers from several limitations. First, the data has been collected only on the sample of macroeconomic data and news press from mergers and acquisitions. The study is focusing mainly on Chinese $M \& A$, the scope of research can is increased in future. The findings of the study need to be validated for the concept of risk to be abandoned as a significant predictor of M\&A.

The study was performed on a macro and microeconomic level, mainly paying attention to Chinese M\&A. Another methodology can be used to determine firms' intention and market entry. The research can be conducted on a firms' level thus determining the direct factors which impact companies' decision and plan to enter and increase foreign markets as M\&A. Also, given the degree of analysis, we relied only on secondary data.

Our study has contributed both theoretically and practically. Contribution to the theory has been made given that we have analyzed M\&A environment for Chinese M\&A, which can also be related to other countries' M\&A. Despite the fact that there is a potential necessity to repeat this examination in subsequent studies, the different hindrances and limitations which were credited to the study, did not decrease the general legitimacy and significance of the exploration, which primarily contributed in characterizing the different viewpoints and attributes of country risk and M\&A relationship. In addition to the recommendations for research that would address the limitations of the study, such as triangulation of methods and going deeper into the strategy domain, we suggest that the concept of risk is explored in relation to other types of market entry, and not only acquisitions. Furthermore, the theory of planned behavior could be an employee to see what makes the CEOs, and firm owners invest in foreign markets. In that way, we will also clarify the role of country risks in intention formation.

\section{REFERENCES}

- Agarwal, J., \& Feils, D. (2007). Political risk and the internationalization of firms: an empirical study of Canadian-based export and FDI firms. Canadian Journal of Administrative Sciences, 24(3), 165, CrossRef

- Albania, financial system stability assessment (February 14, 2014) International Monetary Fund Washington, D.C. https://www.imf.org/external/pubs/ft/scr/2014/cr1479.pdf

- Alfaro, L., Chanda, A., Kalemli-Ozcan, S., \& Sayek, S. (2004). FDI and economic growth: the role of local financial markets. Journal of international economics, 64(1), 89-112, CrossRef

- Anastasia, O., Mbadike, N. S., Anayachukwu, O. B., \& Ezeji, C. E. (2015). Impact of Selected Economic Indicators on Foreign Investment Inflow in Nigeria and South Africa: Optimal Indicators Search. International Journal of Management Science and Business Administration, 1(7), 39-47, CrossRef

- Bevan, A. A., \& Estrin, S. (2004). The determinants of foreign direct investment into European transition economies. Journal of comparative economics, 32(4), 775-787, CrossRef

- Bhagwati, J. N. (1978). Foreign trade regimes and economic development; Anatomy and consequences of exchange control regimes.

- Blomberg, S. B., \& Hess, G. D. (2002). The temporal links between conflict and economic activity. Journal of Conflict Resolution, 46(1), 74-90, CrossRef

- Blomberg, S. B., Hess, G. D., \& Orphanides, A. (2004). The macroeconomic consequences of terrorism. Journal of Monetary Economics, 51(5), 1007-1032, CrossRef

- Borensztein, E., De Gregorio, J., \& Lee, J. W. (1998). How does foreign direct investment affect economic growth?. Journal of International Economics, 45(1), 115-135, CrossRef

- Brassington, F., \& Pettitt, S. (2006). Principles of marketing. Pearson Education.

- Busse, M., \& Hefeker, C. (2007). Political risk, institutions and foreign direct investment. European journal of political economy, 23(2), 397-415, CrossRef 
- Chen, F., \& Wang, Y. (2014). Integration risk in cross-border M\&A based on internal and external resource: empirical evidence from China. Quality \& Quantity, 48(1), 281-295, CrossRef

- Chigbu Ezeji, E., Promise, U. C., \& Chigbu Uzoamaka, S. (2015). Impact of Capital Inflows on Economic Growth of Developing Countries. International Journal of Management Science and Business Administration, 1(7), 7-21, CrossRef

- Chinese Buy Rights to Oil Fields in Albania (March 21, 2016) Retrieved from http://www.balkaninsight.com/en/article/chinese-company-to-take-over-oil-fields-of-albania$\underline{03-21-2016}$

- Chowdhury, A., \& Mavrotas, G. (2006). FDI and growth: What causes what?.The World Economy, 29(1), 9-19, CrossRef

- Demirhan, E., \& Masca, M. (2008). Determinants of foreign direct investment flow to developing countries: a cross-sectional analysis. Prague economic papers, 4(2008), 356-369.

- Dunning, J. H., \& Lundan, S. M. (2008). Multinational enterprises and the global economy. Edward Elgar Publishing.

- Dutta, N., \& Roy, S. (2011). Foreign direct investment, financial development and political risks. The Journal of Developing Areas, 303-327, CrossRef

- Erb, C. B., Harvey, C. R., \& Viskanta, T. E. (1996). Political risk, economic risk, and financial risk. Financial Analysts Journal, 52(6), 29-46, CrossRef

- Hayakawa, K., Kimura, F., \& Lee, H. H. (2013). How does country risk matter for foreign direct investment?. The Developing Economies, 51(1), 60-78, CrossRef

- Hermes, N., \& Lensink, R. (2003). Foreign direct investment, financial development and economic growth. The Journal of Development Studies,40(1), 142-163, CrossRef

- Herndon, T., Ash, M., \& Pollin, R. (2014). Does high public debt consistently stifle economic growth? A critique of Reinhart and Rogoff. Cambridge journal of economics, 38(2), 257-279, CrossRef

- International Country Risk Guide (ICRG), The Political Risk Services.

- Kobrin, S. J. (1979). Political risk: A review and reconsideration. Journal of International Business Studies, 67-80, CrossRef

- Kolstad, I., \& Villanger, E. (2008). Determinants of foreign direct investment in services. European Journal of Political Economy, 24(2), 518-533, CrossRef

- Kolstad, I., \& Wiig, A. (2012). What determines Chinese outward FDI?.Journal of World Business, 47(1), 26-34, CrossRef

- Kotler, P., Armstrong, G., Harris, L., \& Piercy, N. (2005). Principles of marketing. 4. European ed. Harlow: Financial Times.

- Kungwani, P., (2014) Risk Management-An Analytical Study. IOSR Journal of Business and Management

- Nordal, K. B. (2001). Country risk, country risk indices and valuation of FDI: a real options approach. Emerging Markets Review, 2(3), 197-217, CrossRef

- Puranam, P., Singh, H., \& Chaudhuri, S. (2009). Integrating acquired capabilities: When structural integration is (un) necessary. Organization Science, 20(2), 313-328, CrossRef

- Quer, D., Claver, E., \& Rienda, L. (2012). Political risk, cultural distance, and outward foreign direct investment: Empirical evidence from large Chinese firms. Asia Pacific journal of management, 29(4), 1089-1104, CrossRef

- Rasmussen, J. (1997). Risk management in a dynamic society: a modelling problem. Safety Science, 27(2), 183-213, CrossRef

- Reuters, T. (2015). Mergers \& acquisitions review financial advisors.Recuperado de http://dmi.thomsonreuters.com/Content/Files/Global_MA_\% 20Financial_Review. pdf.

- Schüler-Zhou, Y., \& Schüller, M. (2009). The internationalization of Chinese companies: What do official statistics tell us about Chinese outward foreign direct investment?. Chinese Management Studies, 3(1), 25-42, CrossRef

- Simon, J. D. (1982). Political risk assessment-past trends and future prospects. Columbia Journal of World Business, 17(3), 62-71.

- Smith, A. (1776). An inquiry into the nature and causes of the wealth of nations. London: George Routledge and Sons, $\underline{\text { CrossRef }}$ 
- Stellmann, S. (2010). Case Study Japan Airlines. GRIN Verlag. Dealogic, Global M\&A Review First Half 2015, 2015. New York

- Tihanyi, L., Griffith, D. A., \& Russell, C. J. (2005). The effect of cultural distance on entry mode choice, international diversification, and MNE performance: A meta-analysis. Journal of International Business Studies, 270-283, CrossRef

- Umidjon, A., Shuhua, H., Jayathilake, B., \& Renyan, M. (2014). Characteristics of Small and Medium Enterprise Innovativeness: Cases of Uzbekistan and China. International Journal of Management Science and Business Administration, 1(1), 12-27, CrossRef

- UNCTAD, FDI/MNE database (www.unctad.org/fdistatistics)

- UNCTAD, World Investment Report, 2015. New York and Geneva, United Nations World Bank, 2015. Global Development Finance Report. The World Bank, Washington, DC.

- World Bank, 2015. World Development Indicators. World Bank Group. The World Bank, Washington, DC.

- Xia, Z., \& Zhang, X. (2011). Strategic Analysis of Synergistic Effect on M\&A of Volvo Car Corporation by Geely Automobile. iBusiness, 3(01), 5, CrossRef 